\section{ONOMÁVAEIN}

Revista semestral de lingüística, filología y traducción
PONTIFICIA UNIVERSIDAD

\title{
Lexical anglicisms: An analysis of commercials addressed to young children on four Television Channels in Spain ${ }^{1}$
}

\section{Carmen Luján-García}

Universidad de Las Palmas de Gran Canaria

España

\section{(C) $($ (i) $\ominus$}

Carmen Luján-García: Departamento de Filología Moderna, Universidad de Las Palmas de Gran Canaria, España. | Correo electrónico: carmen.lujan@ulpgc.es 


\section{Abstract}

The influence of English in Spanish has led to the use of a considerable number of pure anglicisms to designate child-related concepts. This paper intends to examine the degree of exposure of children to English terms by analysing the increasing presence of anglicisms in Spanish television commercials. With that purpose, the amount and the kinds of anglicisms present on TV commercials of four popular TV channels in Spain (Antena 3, Tele 5, La Sexta and Disney Channel) have been explored. The study reveals that English borrowings are quite present in different subject areas (food and drinks; games and toys; clothes and shoes; personal hygiene; leisure and entertainment). A classification of pure anglicisms, adapted anglicisms, pseudo-anglicisms, and acronyms has been made, and some Anglo-American cultural icons have been analysed. English usage in global advertising is a marker of modernity, progress, sophistication. Findings in this research reveal that children in Spain are considerably exposed to this influence.

Keywords: anglicisms; children; Spain; TV commercials.

1 This paper is the result of a project funded by the Universidad de Las Palmas de Gran Canaria (ULPGC 11-003) entitled Globalización e impacto de la lengua inglesa y la cultura anglo-americana en la publicidad televisiva española. The team working on this project is composed of María Goretti García, María Isabel González Cruz, Ma Jesús Rodríguez under the coordination of Carmen Luján García. 


\section{Introduction}

A great volume of literature has been devoted to deal with the presence of English Ioanwords which have penetrated into different European languages (Görlach, 2002; Anderman and Rogers, 2005; Berns, De Bot and Hasebrink, 2007; Fischer and Pulaczewska, 2008; De Houwer and Wilton, 2011; Furiassi, Pulcini and RodríguezGonzález, 2012). Most of these volumes have focused on the increasing presence of English lexical borrowings which seem to be pervading many different areas and semantic fields of European languages. This fascinating phenomenon reflects how languages live, breathe, change and influence each other as times and societies change as well. Probably one of the most important factors that have influenced languages for this phenomenon to take place is the process of globalisation that most European societies have undergone throughout the last decades. Some decades ago, in every society, there were national and local traditions which identified a specific country and made it different from others. Nowadays, the situation has become quite different, since countries seem to be quite similar in certain aspects. Arnett (2002: 781) reports that "in many cultures today, people who are middleaged or older can remember a time when their culture was firmly grounded in enduring traditions, barely touched by anything global, Western or American. However, few young people growing up today will have such memories in the decades to come. Young people in every part of the world are affected by globalization". SungYul and Wee (2012: 3) report on the unstoppable spread of English across the globe and the increasing belief that English has become the language for global communication.

According to different authors (Dimova, 2012; Martin, 2002, 2006; Ustinova and Bhatia, 2005; Vettorel, 2013), English is globally associated with fashion and modern behaviours. The fact of using English words, names or expres- sions provides the advertised good or product an added value that another television commercial with no English borrowings probably does not have. Friedrich (2002: 25) reports on the traditional connection between English and advertising, since US has spent more money than any other country in ads.

The field of TV commercials is very interesting, as it is a very powerful weapon to persuade people to purchase a certain product. According to data of 2010-2011 (Cultural Statistics Division, Ministry of Education, 2011: 18), 96.6\% of Spanish people watch TV regularly. This habit affects almost the whole population, regardless age, gender or residence with similar intensities.

Regarding the presence of English on television commercials, it is important to remark that everything we watch on a TV commercial is carefully planned, since advertisements are very short and, in that brief period of time, not only they have to catch people's attention, but commercials also have to remain - if possible - in people's memory (Goddard, 1998). Each linguistic item fulfills a function on a television commercial. The use of English terms and which terms has been carefully decided, and these decisions have most probably been made considering the values of fashion and modernity currently associated with the English language.

In some world-wide countries, different studies aiming at analysing the use of anglicisms in TV commercials have been carried out. In South Korea, Lee (2006) found that the mixture of English terms with Korean words in the discourse of television commercials is a "linguistic mechanism for the construction of modernity" (Lee, 2006: 59). In Thailand, some recent research (Sanprasert, 2014) provides evidence of the increasing use of English in Thai mass media through English names, and a mixture of Thai-English ads. In Russia (Ustinova and Bhatia, 2005; Ustinova, 2006), findings reveal the increasing use of English-Russian mix on TV commercials. Dimova 
(2012) also concludes that Macedonian television commercials are under the strong influence of English. In Italy, Vettorel (2013) finds that the presence of English in Italian TV commercials is considerable and plays "a symbolic rather than an informative function" (Vettorel, 2013: 275). In Greece, Oikonomidis (2003) highlights the increasing use of English borrowings in the media. French TV commercials have also been studied (Martin, 2002, 2006, 2007) and despite legislation (1994 Toubon Law), English is the favourite foreign language used in advertisements. In some Spanish-speaking countries like Mexico or Ecuador, different scholars (Baumgardner, 2006; Ovesdotter, 2003) have reported on the pervasive presence of English in the field of ads. As Baumgardner (2006: 252) points out, "English sells". These pieces of research have focused on TV commercials addressed to adults, rather than children as is the case of this study. This is one of the novelties of this analysis. That fact makes a difference, since children do not have the cultural background that adults do. However, the mentioned studies provide some references of what is happening in the examined field in other countries.

\subsection{Theoretical framework}

Spain is an Expanding Circle country within Kachru's typology (Kachru, 1992), since English has been considered not as a second, but as a foreign language in this country. English is becoming more and more present in every aspect of Spaniards' daily life, including the area of television commercials. However, English is not an institutionalized language in this country. In any case, the use of anglicisms is present in many different fields and this fact has made that different typologies of anglicisms (Alfaro, 1948; Pratt, 1980; Lorenzo, 1987) have been made.

In this study, the well-known classification of anglicisms by Lorenzo (1987: 77-79) will be used. Firstly, it is necessary to clarify what is un- derstood by pure anglicisms or English words that keep the same English spelling when these terms are used in another language, in this case, Spanish. It means that no adaptation has been applied to these words. Secondly, adapted ang/icisms are those borrowings that undergo a process of adaptation from English to another language when they are used in the target language. Pseudo-anglicisms or false anglicisms are those terms that are created and produced within one language with an appearance of English, but those words do not exist in the English language or in English they have a different meaning. For example, the term puenting, whose stem is spanish 'puente' (bridge-noun) and the affix -ing expressing an action. This is used to refer to the sport known as bungee jumping. In Spanish, there is the word puentismo (Diccionario panhispánico de dudas), but nobody uses that word. Most people even do not know the Spanish equivalent. Eventually, the category of Acronyms has also been included, as according to Lorenzo's typology (1987), this is also a kind of anglicism.

Different pieces of research have studied the presence of English words, names and expressions in the realm of advertising in Spain. Blanco (1997) reported on the use of TV commercials as useful materials to analyse the use of the language, music and other Anglo-Saxon cultural aspects in the English classroom. Durán Martínez (2002) carried out one of the main studies in the area of advertisements of printed magazines in Spain. This author examined several magazines (El País Semanal, Blanco y Negro, el Magazine, el Semanal and el Dominical) published on Sundays in Spain in March 2000. This research focused on the printed press-magazines-, but without any oral coverage, what makes it different from the present study, which basically deals with the oral language of ads.

It is important to point out that the oral language varies from the written one. The written language tends to be more complex, conserva- 
tive and more reluctant to the inclusion of lexical borrowings, in this case anglicisms, than the oral language (Halliday, 1989, 2007; Ferguson, 1982), whose structure is generally less complex and less conservative. In addition, more than a decade has gone by between both pieces of research and the expansion of the phenomenon of globalisation has basically taken place during this period of time.

In 2007, Gerritsen et al. also researched the use of anglicisms in different fashion magazines in Europe, including Spain, and this study included a brief analysis of a Spanish edition of a fashion magazine. This research, though of great interest, focuses on the written language, rather than oral.

This paper intends to reveal the use of anglicisms, English names and expressions in the area of TV commercials related to children's and babies' products and goods. Another recent paper (Luján-García, 2011) reported on the presence of English in the names of dolls, toys and games in toys leaflets addressed to young children in Spain, and the findings showed that there is an increasing tendency to use English names for dolls, toys and games. In Spain, no previous work has analysed the use of anglicisms in the specific field of TV commercials addressed to young children. Therefore, this study intends to bridge a gap of research in this field.

\section{Research questions}

In broad terms, this study intends to shed some light on the use of anglicisms in TV commercials addressed to children in the context of Spain. Some research questions have been formulated in order to provide an answer for them.

- Do TV commercials addressed to kids use anglicisms to advertise their products?

- What are the main subject areas where anglicisms may be found in the examined ads?
- What kinds of anglicisms are more frequently used in the analysed commercials?

\section{Method}

The method consisted of different steps. First of all, four different channels were chosen (Antena 3, La Sexta, Tele 5 and Disney Channel) in order to have variety of ads and be able to compare results among the different TV channels. The second step consisted of recording TV commercials on these channels. The reason for having chosen these four private TV channels rather than state channels like TVE was because the amount of TV commercials in private channels is higher. These TV channels are currently quite popular in Spain and they have high audience figures. According to data of the National Statistics Institute (INE) in Spain, in 2006, the audiovisual services produced 11.7 billions of Euros. The breakdown of this figure shows that the activities related to the radio and television are $63.4 \%$ of the total, and the rest is produced by cinema and video activities. Regarding the amount of time that Spanish people spend watching TV, figures of 2013-2014 assert that an average Spaniard devotes around 239 minutes per person per day of their free time watching TV (AIMC, 2014: 13). According to AIMC (2014, 13), Tele 5 was the leading channel from October 2013 to May 2014 with an audience figure of $18.1 \%$. This score is followed by Antena 3 with $17.5 \%$ of audience. La Sexta has had $6.6 \%$ of audience during that period of time. Disney Channel is quite far from the above mentioned audience figures. At that period of time, Disney Channel was watched by 7,508 people.

Antena 3 and La Sexta belong to the Spanish audiovisual group AtresMedia, Tele 5 belongs to the enterprise group Mediaset España. The specific case of Disney Channel, which is an international channel of the company Walt Disney, broadcasts in Spain as a free channel, though in many countries it is under payment. This last one, 
Disney Channel, was included in this analysis in order to obtain data of a channel whose target audience were children, the main object of this analysis. Due to the nature of this research, the inclusion of a channel like Disney Channel was considered appropriate.

Therefore, for this study three TV channels addressed to a general audience were chosen in addition to one channel whose target audience is basically children. Obviously, if other state channels like TVE had been chosen or Disney Channel had not been examined, the results could have been a bit different.

Once the recordings were finished, a process of filtering had to be carried out. For the purposes of this study, any TV commercial that was not addressed to children was not examined and any ad that did not contain any English loanword was discarded. The target for this research was only those commercials addressed to children that employed anglicisms. This was part of the process of selection of ads in order to create the corpus to be studied. A worksheet containing various pieces of information of each of commercial was employed. This worksheet was taken from Blanco (1997) and adapted to the specific needs of this study. Some of the details included in the worksheet were: which kind of product was advertised; name of the product; brief description of the commercial; if the message or English word / expression was oral, written or both; the TV channel that was being recorded; date; the anglicism and the complete sentence where it was uttered to have the context where the term occurred.

According to Bhatia (2006: 604), language and medium mixing is intrinsic to ads and commercials. It is written-spoken forms; text-image mixing; music and so on. Most of the anglicisms in this study were uttered, but also some of them were just written in the commercial. All these English terms were included in this research in the section of findings.
The next step involved the organisation of the data of the selected ads considering the frequency of use of anglicisms, the channels were commercials occurred, different subject areas were distinguished, and eventually, the kinds of anglicisms employed.

\subsection{Sample}

The sample was collected in different periods of time from summer 2013 to winter 2015. The purpose of collecting the data in three different periods was basically to have a wide picture of television commercials in Spain. The same kind of advertisements are usually on TV in different channels in the same period, so having different periods of time throughout the year offered a wider sample of commercials.

From July 2013 to January 2015 recordings of the four television channels involved in this study (Antena 3, La Sexta, Tele 5 and Disney Channel) were carried out. The chosen television channels were all private, as they provide a greater amount of commercials than public channels, but despite the fact that these channels are private, they transmit for free-no fee is applied-in Spain.

The examined TV commercials were compiled at two different time zones ( $1^{\text {st }}$ - from $16: 00$ to 17:30; and $2^{\text {nd }}$-Prime Time, from 20:30 to 23:30). The reason why recordings were also carried out during Prime Time (20:30 to 23:30) was because in the morning children are at school, and in the evening, many kids are also in their extracurricular activities. Therefore, even if Prime Time is not probably the most appropriate time for children to watch TV, for many children it is almost the only time they have to watch TV. In addition, this set of recordings during Prime Time also provided a more extensive sample of ads.

\section{Findings}

This section will examine in detail the results obtained in this piece of research. 


\subsection{Breakdown according to channels}

The following Table 1 and Figure 1 present the total amount of TV commercials compiled in the four examined channels during the period of recordings. Table 1 and Figure 1 also provide data of the number of ads with anglicisms, being Antena 3 the one with the highest score $-34.2 \%$ - of the total of TV ads containing some kind of anglicism. In the second position, Tele 5 provided a score of $27.4 \%$ commercials with anglicisms. La Sexta is in the third position with $22.7 \%$ of ads with English loanwords, and finaIly Disney Channel with $15.5 \%$ TV commercials. However, differently from the other channels,
Disney Channel offers the highest score of TV commercials addressed to children, as could be expected. It is $12.7 \%$ of ads out of the total $15.5 \%$ of commercials are addressed to children, and only $2.6 \%$ different ads are addressed to a more general audience.

As a summary of the contents in Table 1 , a total of 595 TV commercials contained some kind of English borrowing during the studied periods. From that amount, 113 ads (18.9\%) were addressed to children, the object of this analysis and the content of our corpus. The rest 482 commercials (81\%) have not been examined in this paper, as they were addressed to adults.

\section{TABLE 1}

Total amount of TV commercials containing anglicisms with a breakdown of the four TV channels

\begin{tabular}{llll} 
TV CHANNELS & \multicolumn{1}{c}{$\begin{array}{c}\text { TV COMMERCIALS } \\
\text { ADDRESSED TO ADULTS }\end{array}$} & $\begin{array}{c}\text { TV COMMERCIALS } \\
\text { ADDRESSED TO CHILDREN }\end{array}$ & TOTAL \\
Antena 3 & $187(31.4 \%)$ & $16(2.6 \%)$ & $203(34.2 \%)$ \\
\hline Tele 5 & $161(27 \%)$ & $4(0.6 \%)$ & $165(27.4 \%)$ \\
\hline La Sexta & $118(19.8 \%)$ & $17(2.8 \%)$ & $135(22.7 \%)$ \\
\hline Disney Channel & $16(2.6 \%)$ & $76(12.7 \%)$ & $92(15.5 \%)$ \\
\hline Total & $482(81 \%)$ & $113(18.9 \%)$ & 595 \\
\hline
\end{tabular}

\section{FIGURE 1}

Breakdown of TV commercials per TV channel

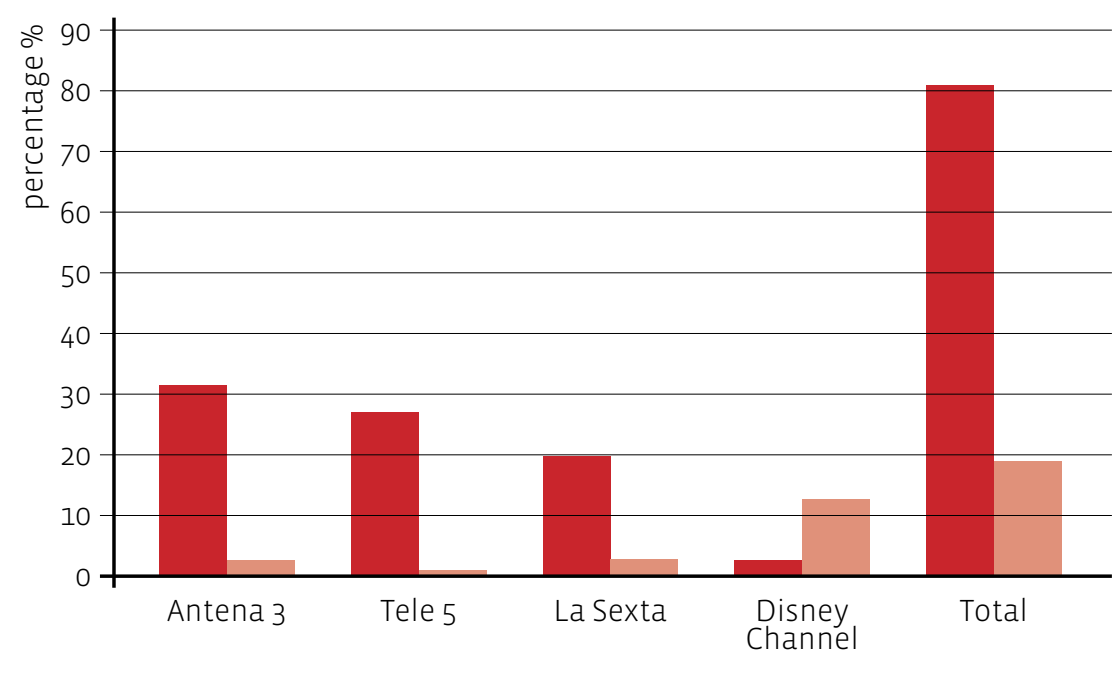

TV commercials addressed to adults

TV commercials addressed to children 


\subsection{Subject areas of TV commercials}

As stated before, the breakdown presented in this and subsequent sections compile only those TV commercials containing anglicisms (written or oral) and advertised goods addressed to children. In order to organise and make sense of the compiled corpus, a classification of different subject areas was made. Five different topics were distinguished in this piece of work, obviously all them addressed to children: Food and drinks; Games and toys; Clothes, shoes and accessories; Personal hygiene and cares; Leisure and entertainment. This classification was carried out considering the topics of the commercials of the compiled corpus.

Table 2 and Figure 2 present a breakdown of the 113 TV commercials considering the different subject areas of the analysed ads. The subject area in which a greater quantity of commercials (46\%) may be observed is "food and drinks". The second subject area with more commercials is "games and toys" with a score of $27.4 \%$ commercials. This finding is also quite predictable, since playing with games and toys is essential for children. "Personal hygiene and cares" is in the third position with a score of $14.1 \%$ com- mercials. The next subject area in terms of quantity of commercials with anglicisms is "leisure and entertainment" with 7\% of ads. Eventually, "clothes, shoes and accessories" is in the last position with a percentage of 5.3\% commercials.

The following figures 3,4 and 5 are samples taken from different TV commercials where English terms may be observed. For example, Figure 3 is one sample of an ad within section "food and drinks" (see Table 2). The word pack is used rather than the Spanish equivalent 'paquete' to refer to the advertised custard.

\section{TABLE 2}

Types of ads with anglicisms

\begin{tabular}{lcc}
\multicolumn{1}{c|}{ KINDS OF PRODUCTS } & $\begin{array}{c}\text { TOTAL } \\
\text { ANGLICISMS }\end{array}$ & $\%$ \\
\hline Food and drinks & 52 & $46 \%$ \\
\hline $\begin{array}{l}\text { Clothes, shoes and } \\
\text { accessories }\end{array}$ & 6 & $5.3 \%$ \\
\hline Leisure and entertainment & 8 & $7 \%$ \\
\hline Games and Toys & 31 & $27.4 \%$ \\
\hline Personal hygiene and cares & 16 & $14.1 \%$ \\
\hline Total & 113 & \\
\hline
\end{tabular}

\section{FIGURE 2}

Main subject areas in TV commercials addressed to children

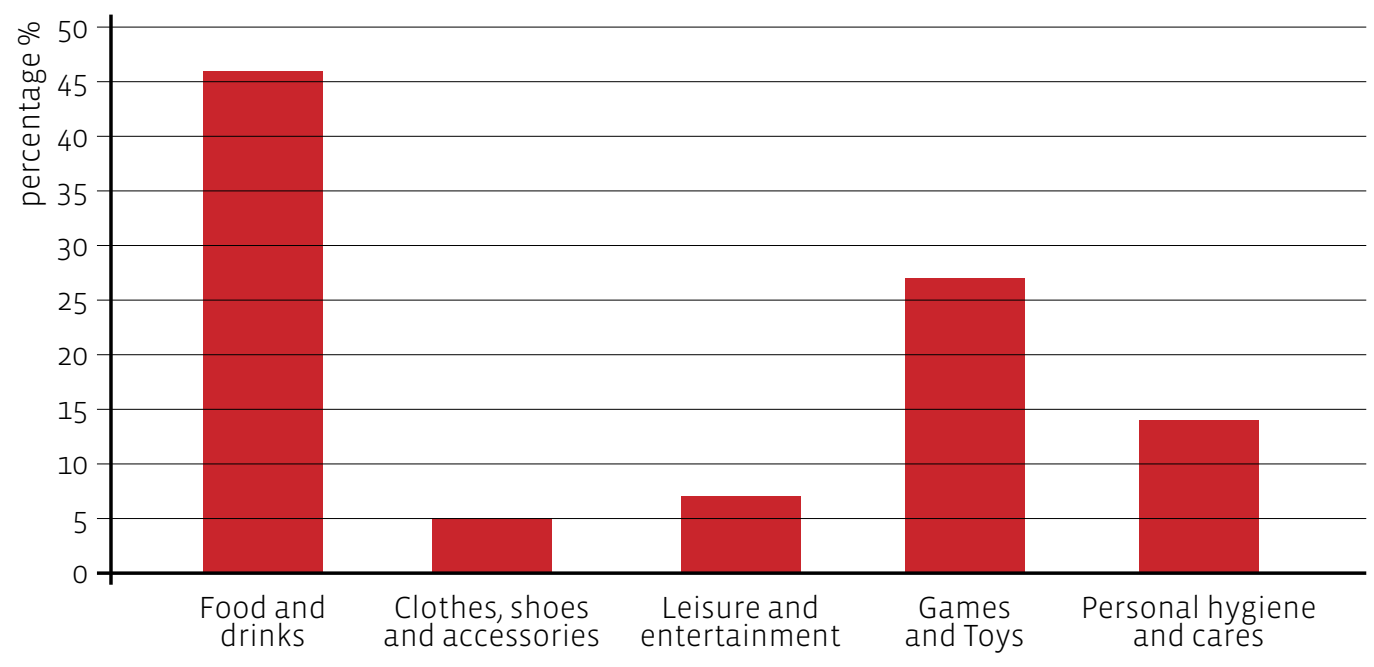




\section{FIGURE 3}

Sample of image of television commercial by Danet (Danone)

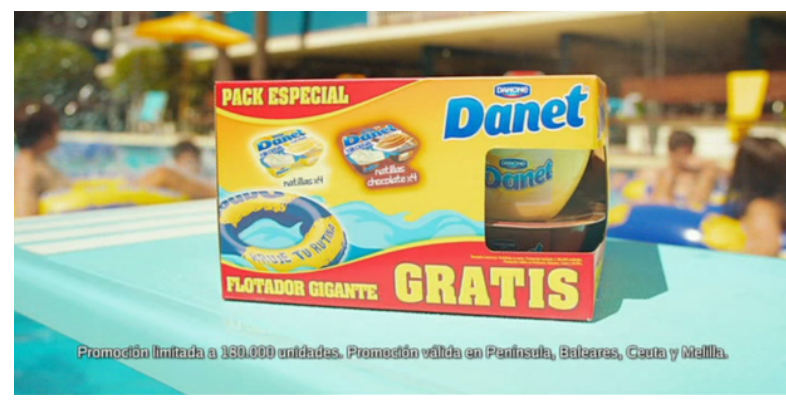

Figure 4 is a sample of a product that is included within the section of "clothes, shoes and accessories" (see Table 2). The name is in English Color me mine in addition to the message be you in one of the hand bags. This good is addressed basically to young girls, and in this case English seems to provide these bags a certain sense of fashion and modernity.

\section{FIGURE 4}

Sample of image of television commercial by Color Me Mine (Cife)

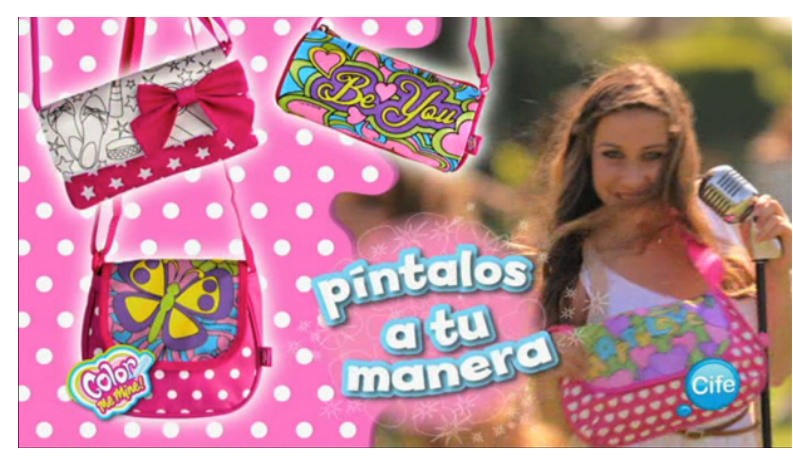

\section{FIGURE 5}

Sample of image of television commercial by McDonald's

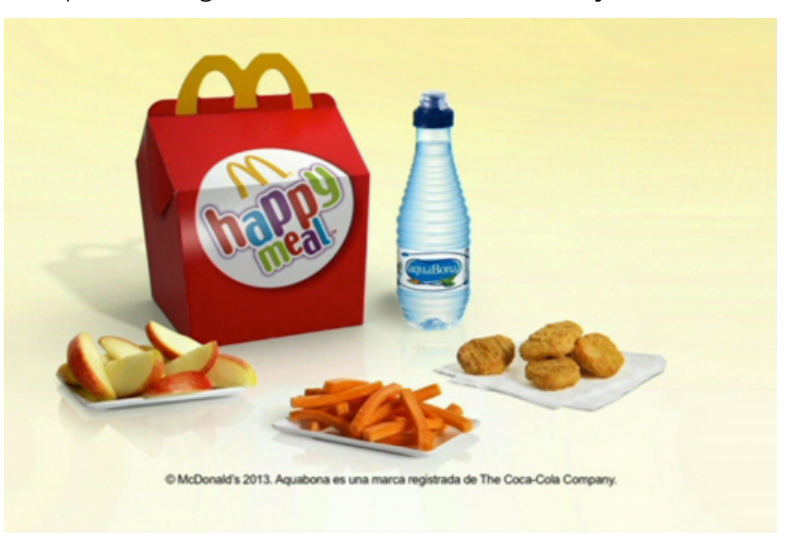

Figure 5 is another sample of a product within section "food and drinks" (see Table 2) and it shows the well-known menu happy meal by McDonald's. This menu could well be in Spanish 'menú feliz', and any child could understand it. However, it is in English.

\subsection{Anglicisms and neologisms}

The following Table 3 presents a breakdown of the different types of anglicisms found in this piece of research. This table contains the total amount and kinds of anglicisms and English words / expressions found in the TV commercials.

The next sections of this paper will describe in detail the different kinds of anglicisms which have been found in the examined television commercials.

\section{TABLE 3}

Breakdown of the different kinds of anglicisms

\begin{tabular}{c|c|c|c|c}
$\begin{array}{c}\text { PURE } \\
\text { ANGLICISMS }\end{array}$ & $\begin{array}{c}\text { ADAPTED } \\
\text { ANGLICISMS }\end{array}$ & $\begin{array}{c}\text { PSEUDO- } \\
\text { ANGLICISMS }\end{array}$ & ACRONYMS & TOTAL \\
98 & 2 & 11 & 2 & 113 \\
$86.7 \%$ & $1.7 \%$ & $9.7 \%$ & $1.7 \%$ & \\
\hline
\end{tabular}




\subsubsection{Pure anglicisms}

A total score of $86.7 \%$ of pure anglicisms have been found in the examined TV commercials. Bhatia and Baumgardner (2008) examined the mixture of English and other Asian languages in TV ads, and these authors distinguished different structural domains within the commercial where the use of English was more frequent. This is known as the Structural Dependency Hierarchy of English in advertising. In the following lines of this paper, a breakdown of the pure English borrowings and expressions will be carried out adapting these authors' hierarchy to the specific context of this study.

With the aim of organising the sample within the category of pure anglicisms, a classification was made:

1. Registered brands and products which are internationally known by their English names will be divided into two sub-groups:

- Product names

- Company names

2. Product names and mottos in English which are used in Spanish TV commercials will be divided into three groups depending on the English word occurrence:

- English phrases incorporated into a commercial

- Product websites

- Written English words in the commercial

\subsubsection{Registered brands and pro- ducts which are internationally known by their English names will be broken down into two sub-groups}

\subsection{Product names}

It is important to distinguish some products that are internationally known by their English names. Many of these product names addressed to children, such as toys and games will be highlighted, as they are used as pure anglicisms with no adaptation to Spanish. Some examples are Monster High Pokemon; Mutant Pollutants; Toy box; Party Princess; Disney Princess; TUC cracker; Fitness; Pediasure; Haribo Gold Bear; Haribo Land; Sunny Delight; Relec; Full Marks; Maxibon Brownie; Drynites.

Twilight Sparkle; Fluttershy; Applejack; Rainbow Dash; Pinky Pie; Cerise Hood; Blondie Locks; Peppa Pig are the given names of different dolls. Animal Crossing; Disney Infinity; Invizimals Play Station are examples of names of games addressed to children and teenagers.

\subsection{Company names}

There are also some registered brands that are known across the globe by their English names. These are the cases of international companies or franchises such as Toys $r$ Us; Fisher Price; McDonald's and Burger King.

\subsubsection{Product names and mottos in English which are used in Spanish TV commercials will be divided into three groups depending on the English word occurrence within the sentence}

\subsection{English phrases incorporated into a commercial}

Some uses of English phrases occur within the TV commercial as complete names and full sentences in English. Some examples of full sentences in English are: Where is my Mickey? Where is my water? I love Minnie; My Little Pony Equestria Girls; Yohoo and Friends; Tamagotchi Friends; Pirate Storm Death or Glory; Mikado King Choco.

In some cases, individual words or combinations of two or more words are also found. These cases will be analysed considering their function within the sentences:

- Some anglicisms have the function of nouns: "Smartphone no incluido" (Cupets- 
Smartphone not included); "El sabores el king" (Burger King-The taste is the King); "Pasátelo happy" (Mc Donald's-Have a great time); "Sube tu actuación más rompedora a nuestra web" (Batidos Puleva-Post your most shocking performance to our website); "Porque me he pasado más juegos que tú en los juegos de tu tablet, no me llames Solita, Ilámame Salón” (Tigretón-Because I have passed more games than you in the tablet games, don't call me Solita, call me Salón); Descárgate las APPs de dibujos (Tosta Rica-Download the apps of drawings); "Yo soy Nerf Rebelle" (I am Nerf Rebelle); "Simon Life" (de zumos Don Simón); "Prueba nuestros nuevos Smoothies y disfruta de todos los sabores solo en junio..." (Burger KingTry our new Smoothies and enjoy all the flavours in June); "Los nuevos bolsos de color change en color me mine" (Color me mineThe new bags by color change in Color me mine); "Prueba Candy \& Crush. Sólo para Facebook, Android, iPhones o iPads" (Candy \& Crush saga-Try Candy \& Crush. Only for Facebook, Android, iPhones or iPads).

Other anglicisms which function as nouns within the sentence are 'tattoos' and 'packs',

\section{FIGURE 6}

Sample of image of television commercial by Simon Life (Don Simón)

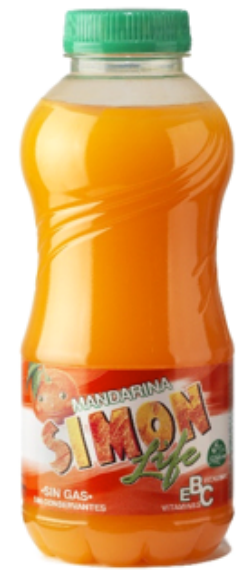

which have equivalents in Spanish (tatuajes for tattoos and paquetes for packs), but some TV commercial choose the English borrowings. "Nuevas Tosta Rica Pou con mis dibujos favoritos y con tattoos de regalo en los packs promocionados" (Tosta Rica- New Tosta Rica with my favourite drawings and with tattoos for you in the promoted packs). There is another case in which the loanword 'tattoo' is chosen against its Spanish equivalent tatuaje. "Ahora La Piara tapa negra te regala brillantes decora uñas y tattoos para que brilles como una estrella" (La Piara-Now, La Piara gives you sparkling nail decorations and tattoos for you to shine like a star); "Hay ocho tattoos distintos" (mini Baby Bel-There are eight different tattoos). The term pack is also frequently used in various products (Custards Danet; Yoghourt Danone; Cocoa Nesquik). Spray is another term employed (Colonia de niños Nenuco). The term 'spray' has an adapted word in Spanish 'espray', but advertisers choose the English term

- Others anglicisms have the function of an adjective: "modo online" (PS3-mode online).

- In other cases, a noun + adjective in English are combined within the same sentence: "Con los nuevos super hot lights de sketchers nunca temerás la oscuridad. Actívales con el botón on /off" (Super hot lightsWith the new super hot lights by sketcher, you won't be scared of darkness. Activate them with the bottom on /off); "Nueva Grand Big Mac, irresistible" (McDonald's); "Bienvenido al Monopoly Junior" (Welcome to Monopoly Junior). In this commercial, you can also see the words pets and sold written in English.

- There is also the case of the conjunction ampersand (\&), which is employed in some cases: Sparkling lemon-lime \& mint drink (Laimon Fresh); Chick \& Share; Candy \& Crush; Pans \& Company. 
- The use of the inflected construction can also be observed in a shampoo advertisement Johnson's baby and the chips commercial Lay’s.

\subsection{Product websites}

Some names of websites and email addresses are also included in this section, as they appear in some of the television commercials. Such are the cases of www.everafterhigh.es; www. YouTube.com/maxibon; www.facebook.com/colacao; www.Clubpenguin.es; Navifun@navifunmadrid; www.real-life.es.

\subsection{Written English words in the commercial}

There are also pure anglicisms which only appear in their written form. In some cases, they occur as complete sentences in English, but in other cases, a combination of two or more terms in English is used.

Some examples of full written sentences in English are: "Do not stack above this line" (Theme Park Disneyland Paris); "Superman and all related characters and elements are trademarks of DC Comics" (Parque Warner Madrid); "I'm loving it" (McDonald's); "Have it your way" (Euroking); Sparkling lemon-lime \& mint drink 100\% natural ingredients and juices-Green me open nature!" (Laimon Fresh); "I'm hungry” (Tamagotchi Friends); "Show off with sparkle" (Twinkle toes)

Other cases in which a combination of two or more English loanwords may be observed are: "Real life / London International High School" (website Real Life); "Playmobil city action / Playmobil country; Playmobil dragons" (Playmobil); "Latest styles" (Twinkle toes); "Soothing spa" (Soothing spa); "New feature on / off" (Super hot lights); "Creative / glop games" (Elastic color); "Tigretón Rock / Tigretón Roll” (Tigretón); “Orlando Resort” (Cocoa Nesquik); "Captain America / the Winter soldier / Super Soldier gear” (Helmet Cap- tain America); "Best buy consumer products" (Carrefour); "Carrefour Market" (Carrefour),"sports" / "Penalty round" (Chick\&Share); "Intense Color Cream" (Schwarzkopf).

\section{FIGURE 7}

Sample of image of television commercial by Full Marks

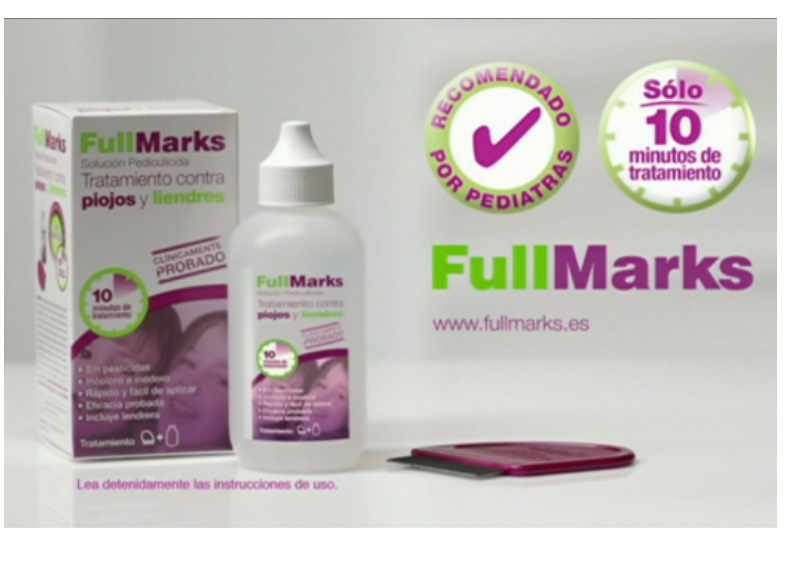

Figure 7 advertises an anti-louse product, but the brand chooses English rather than Spanish to name this treatment. Figure 8 is an image of an advertisement of a type of cheese addressed mainly to children and the word baby is employed instead of Spanish 'bebé'.

\section{FIGURE 8}

Sample of image of television commercial by Mini Babybel

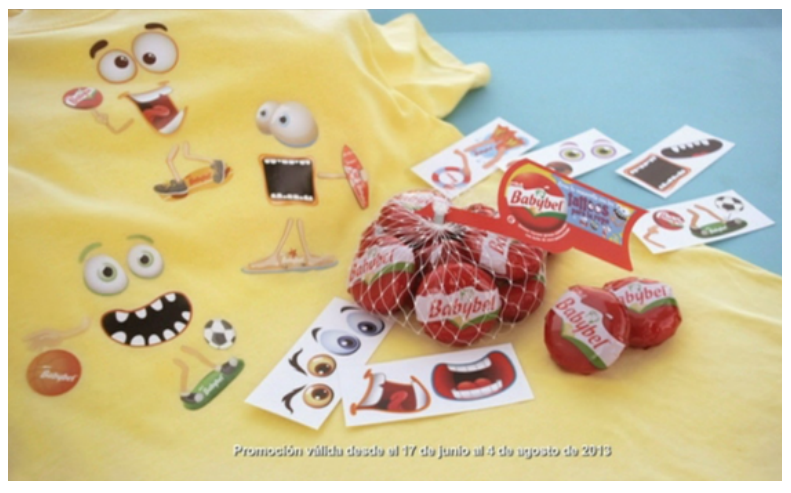

This section of pure anglicisms presents the highest amount of English borrowings shown on TV commercials. 


\subsubsection{Adapted anglicisms}

Some words have undergone a process of adaptation. One example is the term 'donut', from English 'doughnut'. This term has Spanish equivalents such as 'berlina' or 'rosquilla'. However, the anglicism is so extended among the users of the language that not only it has been adapted to Spanish, but it is also widely used by any Spanish speaker, even more than its equivalents ("Ahora me comería un donut"). Another example is the word 'champú', employed in the TV ads by Johnson's baby and Full Marks. It comes from English 'shampoo', and it has been adapted to Spanish phonology.

\subsubsection{Pseudo-anglicisms}

In the language of commercials, the creativity is one of the tools employed to catch the audience's attention. One of the strategies used is the creation of new terms by combining English and Spanish. These terms are neologisms that have an English appearance but they do not really exist or they have a different meaning in English.

To illustrate, a word like quickydelicioso is formed with the English stem 'quick' and the Spanish conjunction y (meaning 'and') and the Spanish adjective delicioso (delicious). Therefore, this new term means that this kind of yoghourt is quick to eat and has a delicious taste. Natuchips is another example of a pseudo-anglicism which combines the stem 'natural' (which has the same spelling in English and Spanish) with the English affix 'chips'. One more example is promoweeks, formed by the combination of the Spanish stem 'promoción' (sale) and the English affix 'weeks'. Cupets is another case of pseudo-anglicisms, a term created after combining the words 'cube' and 'pets'. Superliquidator is another pseudo-anglicism, since it is used to name a toy, more specifically a gun. In English, according to Macmillan Online Dictionary, liqui- dator is applied to "someone who liquidates a company so that it can pay the money it owes". Thus, a new use of the term liquidator in English has been created in Spanish to call this toy.

Another example is the case of pringoooooals, which is a word play that combines the name of the advertised product Pringles and the term goals. This is one more example of the invention of a new term with English appearance, but with no meaning in English. The case of the advertised product "Laimon Fresh". The word 'laimon' has been spelled from the English term 'Iemon'. In Spanish, there is the word 'limón', so maybe, this television commercial displayed certain creativity with the new word 'laimon', which is midway between 'limón' and 'lemon'. It is also remarkable the word order, since 'laimon' is a noun and 'fresh' is an adjective. This is the regular word order in Spanish, but not in English, which should be adjective + noun ('fresh laimon').

An advertised good that combines a Spanish term with an English word is the case of Nenuco Baby. Nenuco is a way to call a little child in Spanish, and baby, which is used to specify that this doll is a baby. Another example is the air freshener Air Wick Nenuco, which uses two English words air and wick with the Spanish term Nenuco; Almirón Advance (milk for babies) and Hero Baby (fruit cocktail for babies) are two more illustrations of the mixture of an anglicism with the advertising brand name.

\subsubsection{Acronyms}

The acronym is another kind of loanword that has been found in some TV commercials. Two acronyms have been found in the examined sample. One of them is OTC, which is the name of an anti-louse shampoo, and these acronyms stand for the English words On the Counter. It means that this product does not require medical prescription to buy it despite the fact that it is sold at chemists. Most users of this product 
probably do not know the real meaning of OTC. However, this brand chooses English to name its product. The second example is Nintendo 3 DS. The acronyms DS stand for Dual Screen. Similarly, quite probably most users of this product do not know the meaning of DS, but they use the term

\subsubsection{Cultural images}

Some symbols related to Anglo-American culture are also present in the examined commercials. In the commercial by Donut, a man disguised and singing like Elvis Presley may be observed. In the ad by Mini Baby Bel, there is also a man who speaks Spanish with an English accent. This is also the case of the television commercial by Vichy Catalán, where the words "Ginseng and Guaraná” may be heard with an English accent, rather than Spanish.

Other examples of cultural images are songs which are played during the advertisement with messages like "We're gonna have fun" (sung by actors in the commercial NEOX Kidz) or "Wake up the baby inside you" (sung by children in the commercial by Dodot). These songs might well be sung in Spanish or any other language, but they are in English.

\section{FIGURE 9}

Sample of image of television commercial by Air Wick

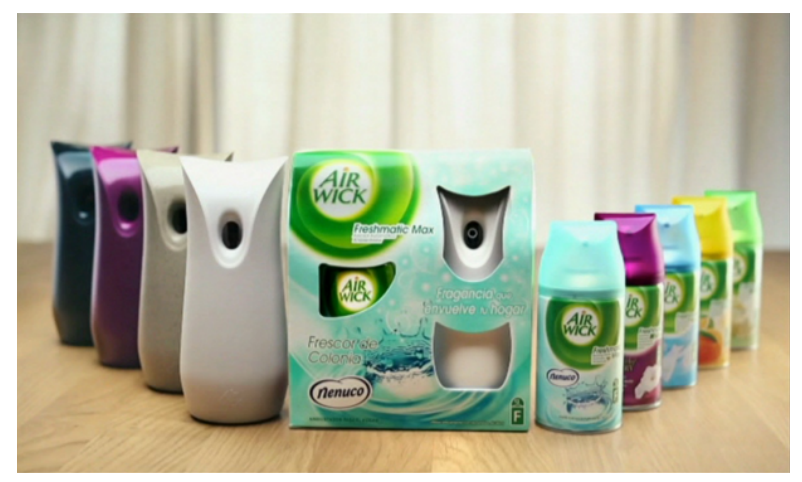

In Figure 9, the name of the air freshener is in English Air Wick in addition to the message Freshmatic Max.

\section{Conclusions and discussion}

This paper sheds some light on the impact of English and Anglo-American culture in the field of television commercials addressed to young children in Spain.

In a nutshell, the subject areas where more anglicisms may be observed are "food and drinks" followed by "games and toys". The kind of English borrowings more frequently used are pure ang/icisms or English terms that are used in Spanish, as they are employed with no adaptation to Spanish spelling or pronunciation. These English loanwords occur in various forms in TV commercials: in the oral or the written language; as individual terms within a sentence or as complete sentences in English; as pure anglicisms, adapted anglicisms, pseudo-anglicisms or acronyms. There are even cases in which this Anglo-American influence may be observed not in linguistic items but through some cultural images or icons.

The most noticeable detail in this study is that all of the examined advertised goods in this study are related to childhood, so they are obviously addressed to young children. Some important implications may be derived. Children seem to be exposed to English in every setting (food, toys, leisure, clothes, personal cares) since a very young age. This fact leads one to wonder to what extent do these children understand what they listen to and read in these television commercials, and to what extent they associate English with objects they like. This paper provides evidence of the continuous exposure of Spanish children to English and calls to reflection on the long-term effects this exposure may have on these kids in terms of cultural identity and presence of English in their daily life.

What is far from question is that the new generations of children, differently from older generations, see the English language as part of their daily life. Therefore, the degree of familiarity and exposure to English of these children is 
much higher than older generations of Spanish children like my own generation. I do not remember to call my dolls, toys or food with an English name. My daughter uses English naturally to refer to these goods.

Focusing on Korean, Lee (2014: 47) points out that "outperforming grandchildren verbally challenge underperforming grandparents and this is mainly due to asymmetric linguistic power English proficiency". Young Spaniards, as young Koreans, are able to understand more easily all those anglicisms, neologisms and hybridised linguistic innovations than their grandparents. Consequently, these young generations are also more ready and eager to use those new terms in their communication.

The results of this piece of research encourage reflection about whether this sociolinguistic phenomenon may have long-term effects on children's linguistic and social identity, or whether this is merely a trend with no future implications on Spanish children's cultural identity. Once more, time will be needed to provide an answer, but current new generations of Spanish children are considerably different from elder generations when it comes to exposure to English and Anglo-American values.

It would be of great interest to conduct similar research in other countries to contrast the results found in Spain. It would also be interesting to carry out research involving the attitudes and perceptions of young consumers to find out the extent to which they understand and use those terms in their daily life or whether this is just a special-creative language used in commercials.

\section{References}

AimC, Asociación para la Investigación de los Medios de Comunicación, 2014: EGM Resumen General Octubre 2013 a Mayo 2014 [file:///C:/Users/CARMEN/ Downloads/resumegm214.pdf, last accessed 6th April 2015].
Alfaro, Ricardo, 1948: "El anglicismo en el español contemporáneo", Thesaurus 4, 102-128.

Anderman, Gunilla, and Margaret Rogers (eds.), 2005: In and Out of English: For Better, For Worse? Clevedon: Multilingual Matters Ltd.

Arnett, J. J., 2002: "The psychology of globalization", American Psychologist 57 (10), 774-783.

Baumgardner, Robert J., 2006: "The appeal of English in Mexican commerce", World Englishes $25(2), 251-266$.

Berns, Margie, K. de Bot and U. Hasebrink (eds.), 2007 : The Presence of English. Media and European Youth, New York: Springer.

BhatiA, Tej K., 2006: "World Englishes in Global Advertising" in Braj B. KaChru, Yamuna KaChru and Cecil NeLson (eds.): The Handbook of World Englishes, Malden, MA: Blackwell, 601-619.

Bhatia, Tej K., and Robert Baumgardner, 2008: "English in the Media and Advertising" in Braj Kachru, Yamuna Kachru and N. Sridhar (eds.): Language in South Asia, Cambridge: Cambridge University Press, 377-394.

Blanco, J. Antonio, 1997: "Tratamiento del mundo anglosajón en la publicidad televisiva en Espaก̃a: 1996", Comunicar 9, 159-162.

Cultural Statistics Division (Ministry of Culture), 2011: Survey on Cultural Habits and Practices in Spain 2010-2011. Synthesis of results [http:// es.calameo.com/read/00007533595fed484978c, last accessed 4th April 2015].

De Houwer, Annick, and Antije Wilton (eds.), 2011: English in Europe Today, Amsterdam: John Benjamins Publishing.

Dımova, Slobodanka, 2012: "English in Macedonian television commercials", World Englishes $31(1), 15-29$. 
Durán Martínez, Ramiro, 2002: La lengua inglesa en la publicidad española: una aproximación pragmática. Tesis doctoral, Universidad de Salamanca en Salamanca.

Ferguson, Charles, 1982: "Simplified registers and linguistic theory" in L. K. Obler, L. Menn (eds.), EXceptional language and linguistics, New York, Academic Press, 49-68.

Fischer, R., and Hanna Pulaczewska (eds.), 2008: Anglicisms in Europe. Linguistic Diversity in a Global Context, Newcastle, UK: Cambridge Scholars Publishing.

Friedrich, Patricia, 2002: "English in advertising and brand naming: sociolinguistic considerations and the case of Brazil", English Today 71, 18 (3), 21-28.

FurIASI, Cristiano, Virginia Pulcinı and Félix RodríGuez-GonzAlezz (eds.), 2012: The Anglization of European Lexis, Amsterdam and Philadelfia: John Benjamins.

Gerritsen, M., C. Nickerson, A. Van Hooft, F. Van Meurs, U. Nederstigt, M. Starren, R. Crijns, 2007: "English in product advertisements in Belgium, France, Germany, the Netherlands and Spain", World Englishes 26 (3), 291-315.

Goddard, Angela, 1998: The Language of Advertising. Written Texts, New York: Routledge.

GöRlACH, Manfred (ed.), 2002: English in Europe, Oxford: O. U.P.

Halliday, M. A. K., 1989: Spoken and written language, Oxford: O. U.P.

Halliday, M. A. K. 2007 [1979]: "Differences between Spoken and Written Language" Language and Education 9.

INE (Instituto Nacional de Estadística), 2008: Cifras INE. Boletín Informativo del Instituto Nacional de Estadística. El Ocio en Cifras [http://www.ine. es/revistas/cifraine/0408.pdf, last accessed 4th April 2015].

KAChru, Braj B. (ed.), 1992: The Other Tongue: English across Cultures, Urbana: University of Illinois Press.

LEE, Jamie Shinhee, 2006: "Linguistic construction of modernity: English mixing in Korean television commercials", Language in Society 35, 59-91. LeE, Jamie Shinhee, 2014: "English on Korean television", World Englishes 33 (1), 33-49.

LoREnZo, Emilio, 1996: Anglicismos hispánicos, Madrid: Gredos

Lujan-García, Carmen, 2011: “English 'invasion' in Spain: An analysis of toys leaflets addressed to young children", English Today 3, 3-9.

Macmillan Online Dictionary [http://www.macmi Ilandictionary.com/, last accessed 4th June 2014].

Martin, Elizabeth, 2002: "Cultural images and different varieties of English in French television commercials", English Today 72, 18 (4), 8-20.

MARTIN, Elizabeth, 2006: Marketing identities through language: English and global imagery in French Advertising, Basingstoke: Palgrave Macmillan.

Martin, Elizabeth, 2007: “'Frenglish' for sale: multilingual discourses for addressing today's global consumer", World Englishes 26 (2), 170-186.

Oıкоnomidis, Agapios, 2003: "The impact of English in Greece”, English Today 74, 19 (2), 55-61.

Ovesdotter Alm, Cecilia, 2003: "English in the Ecuadorian commercial context", World Englishes 22 (2), 143-158.

Pratt, Chris. 1980. El anglicismo en el español peninsular contemporáneo, Madrid: Gredos.

Real Academia Española, 2005: Diccionario panhispánico de dudas [http://goo.gl/VFAsQY, last accessed 14th September 2014]. 
Sanprasert Snodin, Navaporn, 2014: "English naming and code-mixing in Thai mass media", World Englishes 33 (1), 100-111.

Sung-Yul Park, Joseph, and Lionel Wee, 2012: Markets of English: Linguistic Capital and Language Policy in a Globalizing World, New York: Routledge.

Ustinova, Irina P., and Tej K. Bhatia, 2005: "Convergence of English in Russian TV commercials", World Englishes 24 (4), 495-508.

Ustinova, Irina P., 2006: "English and emerging advertising in Russia”, World Englishes 25 (2), 267277.

Vettorel, Paola, 2013: "English in Italian advertising”, World Englishes 32 (2), 261-278. 